\title{
ANALISIS PENGARUH VARIABEL EKONOMI TERHADAP PERTUMBUHAN EKONOMI DI KABUPATEN HALMAHERA TIMUR
}

\author{
Hilman Duko \\ Paulus A.Pangemanan \\ Theodora M. Katiandagho
}

\begin{abstract}
This study aims to (1) determine the influence of labor, investment, inflation rate, and change of head of region to economic growth in East Halmahera Regency at North Maluku Province, during the period 2004-2014, (2) and calculate the economic growth rate until 2019 based on the dominant economic sector. The type of research using library research method using PDRB data, East Halmahera Regency during 2004-2014 period published by Central Statistics Agency which calculated based on constant price in 2000. Model estimation results are calculated with the help of SPSS applications. The results showed the three variables (economic growth, labor, investment, and inflation) partially influence significantly to the variable of economic growth. While, the variable of Pilkada's existence was not gave a significant effect on economic growth. The average rate of economic growth generated by the government and society in this regency is cumulatively reaching $8.18 \%$ per year.
\end{abstract}

Keywords:labor, investment, inflation rate, head of region, calculate the economic growth rate

\begin{abstract}
ABSTRAK
Penelitian ini bertujuan untuk (1) menentukanpengaruh tenaga kerja,penanaman modal (investasi), tingkat inflasi,dan pergantian kepala daerah terhadap pertumbuhan ekonomi di Kabupaten Halmahera Timur Provinsi Maluku Utara selama periode 2004-2014, (2) serta menghitung laju pertumbuhan ekonominya sampai tahun 2019 berdasarkan sektor ekonomi yang dominan.Jenis penelitian dengan metode studi perpustakan (Library research) menggunakan data PDRB, Kabupaten Halmahera Timur selama periode 2004-2014 yang diterbitkan Badan Pusat Statistik yang dihitung berdasarkan harga konstan (constant price) tahun 2000. Data dianalisis dengan menggunakan model logaritma ganda. Hasil pendugaan model dihitung dengan bantuan aplikasi SPSS. Hasil penelitian menunjukkan bahwa (1) ketiga variabel yaitu tenaga kerja, investasi, dan tingkat inflasi secara parsial mempengaruhi secara signifikan terhadap variabel pertumbuhan ekonomi. Sedangkan variabel keberadaan Pilkada tidak berpengaruh sinifikan terhadap pertumbuhan ekonomi.(2) Rata-rata tingkat laju pertumbuhan ekonomi yang dihasilkan pemerintah dan masyarakat di kabupaten ini secara kumulatif mencapai 8,18\% per tahun.
\end{abstract}

Kata kunci: tenaga kerja, investasi, tingkat inflasi, pergantian Kepala Daerah, laju pertumbuhan ekonomi

\section{PENDAHULUAN}

\section{Latar Belakang}

Perekonomian Indonesia mengalami pertumbuhan yang cukup tinggi dalam periode tahun 2004-2014. Secara nasional, tingkat laju pertumbuhan ekonomi yang diukur menggunakan perkembangan Produk Domestik Bruto atas dasar harga konstan, meningkat dari $\mathrm{Rp} 1.656 .516,8$ triliun pada tahun 2004 menjadi Rp 2.909.181,5 triliun pada tahun 2014 atau tumbuh rata-rata 7,56 $\%$ per tahun. Tingkat laju pertumbuhan ekonomi yang demikian tinggi tersebut, didorong oleh berbagai faktor di antaranya perkembangan investasi dalam negeri dan investasi asing yang relatif besar, pengeluaran konsumsi masyarakat dan tingkat kesempatan kerja yang cukup tinggi, laju inflasi yang relatif terkendali, serta tabungan 
masyarakat dan ekspor yang terus meningkat. Perkembangan berbagai variabel makroekonomi nasional yang semakin baik tersebut memberi isyarat bahwa, selama periode 2004-2014, pemerintah berhasil dalam mendorong pelaksanaan pembangunan ekonomi di Indonesia. Pertumbuhan ekonomi nasional yang relatif baik periode 2004-2014 sebagaimana dikemukakan di atas, tentunya akan berimplikasi positif terhadap perkembangan kondisi makroekonomi regional di berbagai daerah di Indonesia. Kondisi ini disebabkan laju pertumbuhan ekonomi nasional yang tinggi, yang tercermin pada peningkatan Produk Domestik Bruto (PDB) riel, selain merupakan akumulasi dari peningkatan Produk Domestik Regional Bruto (PDRB) riel di berbagai daerah di Indonesia. Di samping itu juga, pertumbuhan ekonomi nasional yang tinggi mereflekasikan semakin baiknya pengelolaan berbagai aspek besaran-besaran makroekonomi regional seperti tingkat kesempatan kerja dan pengangguran, uang beredar dan tingkat bunga, inflasi dan hargaharga, penanaman modal (investasi), konsumsi daerah, pajak serta perdagangan dalam dan luar negeri, yang pada akhirnya akan bermuara pada peningkatan produksi daerah. Pengelolaan berbagai aspek besaran-besaran makroekonomi regional yang semakin baik, yang menghasilkan produksi daerah yang terus meningkat, akan berkontribusi besar dalam mendorong peningkatan produksi dan laju pertumbuhan ekonomi nasional.

Kebijakan lain yang ditempuh pemerintah Indonesia untuk mempercepat proses pemulihan kondisi ekonomi nasional yang dilanda krisis adalah dengan melakukan perubahan terhadap kebijakan pembangunan ekonomi daerah melalui pembaruan Undang-undang Otonomi Daerah (Undang-undang Nomor 32 Tahun 2004 tentang Pemerintahan Daerah dan Undang-undang Nomor 33 Tahun 2004 tentang Perimbangan Keuangan Antara Pemerintah Pusat dan Pemerintah Daerah). Perubahan tersebut dilakukan melalui penyerahan sebagian kewenangan pemerintah pusat kepada pemerintah daerah melalui kebijakan desentralisasi untuk menggali dan mengembangkan berbagai potensi perekonomian daerah. Selain bertujuan agar pemerintah daerah memiliki peluang dalam mengembangkan berbagai kebijakan ekonomi regional untuk mengoptimalkan pendayagunaan potensi ekonomi di daerahnya (Syaukani, 2002). Di samping itu, fundamental ekonomi daerah akan menjadi semakin kuat, karena proses pemberdayaan berbagai potensi ekonomi dapat dilakukan secara signifikan dengan kemampuan yang lebih besar melalui pengembangan berbagai kebijakan ekonomi regional (Rasyid dkk, 2002).

Perubahan kebijakan pembangunan ekonomi daerah melalui penerapan desentralisasi kewenangan dalam menggali dan mengembangkan berbagai potensi perekonomian daerah, memberikan implikasi yang positif terhadap perkembangan besaran-besaran makroekonomi regional di berbagai daerah di Indonesia termasuk di Kabupaten Halmahera Timur. Produksi barang dan jasa yang mencerminkan laju pertumbuhan ekonomi dan perubahan struktur ekonomi daerah meningkat. Demikian pula peningkatan dalam berbagai indikator makroekonomi ragional lainnya seperti investasi, kesempatan kerja, tabungan masyarakat, pengeluaran konsumsi dan ekspor, yang diikuti oleh semakin terkendalinya tingkat inflasi dan pengangguran angkatan kerja yang rendah. Kondisi yang demikian memberikan petunjuk bahwa, perubahan kebijakan pembangunan ekonomi daerah, tidak hanya berimplikasi terhadap pertumbuhan dan perubahan struktur ekonomi daerah, tetapi juga meningkatkan taraf hidup dan tingkat kesejahteraan masyarakat di berbagai daerah di Indonesia.

Di Kabupaten Halmahera Timur, laju pertumbuhan ekonomi berfluktuasi dalam periode 2004-2014. Selain itu, struktur pertumbuhan ekonomi di Kbupaten ini cenderung terkonsentrasi pada sektor-sektor ekonomi tertentu dengan kontribusi yang cukup besar.

Secara teoritis, terdapat banyak sekali faktor yang berpengaruh terhadap masalah tersebut. Rahardja dan Manurung (2005) mengemukakan tujuh faktor yang mempengaruh terhadap pertumbuhan ekonomi, yaitu:

(1) Stok Barang Modal (Investasi),

(2) Jumlah Tenaga Kerja,

(3) Tingkat Teknologi,

(4) Pendapatan (Uang),

(5) Manajemen,

(6) Kewirausahaan, Dan

(7) Informasi. 
Sementara Suparmoko (2000) hanya mengemukakan enam faktor, di antaranya adalah tenaga kerja, kapital, tingkat inflasi, barang sumberdaya alam, tingkat teknologi, dan kondisi sosial masyarakat. Kondisi sosial di sini dimaksudkan sebagai keadaan atau sistem yang diperlukan untuk mendukung sasaran pencapaian laju pertumbuhan ekonomi seperti kondisi keamanan, politik, adat-istiadat, agama, sistem pemerintahan, dan lain sebagainya.

Dengan asumsi faktor-faktor lain konstan (ceteris paribus), penelitian ini hanya diarahkan untuk mengkaji empat dari berbagai faktor tersebut dikaitkan dengan pertumbuhan ekonomi di Kabupaten Halmahera Timur yaitu:

(1) Tenaga kerja,

(2) penanaman modal (investasi),

(3) tingkat inflasi, dan

(4) dummy variabel pergantian Kepala Daerah yang merefleksikan variabel kondisi sosial politik masyarakat.

\section{Rumusan Masalah}

Pembangunan ekonomi di Kabupaten Halmahera Timur periode 2004-2014 mengalami peningkatan setiap tahun didalam kontribusi sektoral terhadap tingkat pertumbuhannya fluktatif ekonomi dari tahun ke tahun pertumbuhan ekonomi ini terjadi akibat pertumbuhan sektor-sektor ekonomi, karena itu substansi permasalahan yang ditelaah dalam penelitian ini dapat dirumuskan sebagai berikut:

1. Apakah tenaga kerja, penanaman modal (investasi), tingkat inflasi, dan masa pergantian kepala daerah berpengaruh terhadap pertumbuhan ekonomi di Kabupaten Halmahera Timur?

2. Berapa besar laju pertumbuhan ekonomi di Kabupaten Halmahera Timur pada tahun 2017 dan faktor-faktor apa yang dominan menentukan pertumbuhan ekonomi dimaksud?

\section{TujuanPenelitian}

Penelitian ini dilaksanakan dengan tujuan untuk:

1. Menganalisis pengaruh tenaga kerja, penanaman modal (investasi), tingkat inflasi, dan pergantian kepala daerah terhadap pertumbuhan ekonomi di Kabupaten Halmahera Timur periode 2004-2014.
2. Menghitung laju pertumbuhan ekonomi Kabupaten Halmahera Timur sampai dengan 2019 berdasarkan sektor ekonomi yang dominan.

\section{Manfaat Penelitian}

Hasil penelitian ini diharapkan dapat digunakan sebagai:

1. Bahan masukan (input) bagi Pemerintah Kabupaten Halmahera Timur dalammerumuskan berbagai kebijakan yang berhubungan dengan upaya peningkatan laju pertumbuhan ekonomi daerah.

2. Bahan bandingan bagi peneliti lain yang berkeinginan melanjutkan penelitian ini, baik sebagai kelanjutan dari penelitian ini di daerah yang sama ataupun di daerah lainnya.

\section{METODOLOGI PENELITIAN}

\section{Lokasi dan Waktu Penelitian}

Penelitian ini dilaksanakan di Kabupaten Halmahera Timur dan berlangsung dari bulan November 2016 hingga bulan April 2017. Pemilihan kabupaten ini sebagai lokasi penelitian didasarkan pada pertimbangan sebagai berikut:

1. Kabupaten Halmahera Timur merupakan salah satu daerah otonomi baru yang dimekarkan pada tahun 2003

2. Kabupaten Halmahera Timur adalah salah satu kabupaten tertinggal di provinsi Maluku Utara, sesuai dengan Peraturan Presiden (perpres) Nomor 131/2015 tentang Penetapan Daerah Tertinggal Tahun 2015-2019.

\section{Jenis dan Sumber Data}

Data yang diambil dalam penelitian ini adalah data sekunder, adapun data yang diambil yakni:

1. Pertumbuhan PDRB atas dasar harga konstan.

2. Tenaga Kerja Kabupaten Halmahera Timur.

3. Investasi Kabupaten Halmahera Timur.ni:

4. Inflasi Kabupaten Halmahera Timur.

5. Masa pergantian kepala Daerah.

Data-data diperoleh dari Kantor Badan Pusat Statistik (BPS), Kantor Dinas Penanaman Modal, dan Kantor Komisi Pemilihan Umum (KPUD) Kabupaten Halmahera Timur, serta Kantor Badan Pusat Statistik (BPS) Provinsi Maluku Utara. 


\section{Definisi Operasional Variabel}

Agar semua variabel yang diteliti menjadi jelas baik pengertian maupun satuan ukurnya, maka dalam penelitian ini variabel-variabel tersebut didefinisioperasionalkan pengertiannya sebagai berikut:

1. Variabel tidak bebas pertumbuhan ekonomi (Y) adalah tingkat laju pertumbuhan Produk Domestik Regional Bruto (PDRB) riel di Kabupaten Halmahera Timur, yang besaran variabelnya dinyatakan dalam satuan persen $(\%)$.

2. Variabel-variabel bebas $(\mathrm{X})$ adalah variabel yang mempengaruhi pertumbuhan ekonomi yang terdiri dari:

a. Tenaga kerja $\left(\mathrm{X}_{1}\right)$, adalah jumlah tenaga kerja yang bekerja pada berbagai sektor ekonomi di Kabupaten Halmahera Timur, yang besaran variabelnya dinyatakan dalam satuan orang.

b. Investasi $\left(\mathrm{X}_{2}\right)$, adalah jumlah investasi swasta yang ditanamkan oleh para pengusaha pada berbagai sektor kegiatan ekonomi di Kabupaten Halmahera Timur, yang besaran variabelnya dinyatakan dalam nilai Rupiah (Rp).

c. Inflasi $\left(\mathrm{X}_{3}\right)$ adalah tingkat inflasi di Kabupaten Halmahera Timur, yang diproksi menggunakan perkembangan Indeks Harga Konsumen (IHK) di Kota Ternate, yang besaran variabelnya dinyatakan dalam satuan persen (\%).

d. Masa Pergantian Kepala Daerah $\left(\mathrm{X}_{4}\right)$ adalah pergantian Kepala Daerah di Kabupaten Halmahera Timur, baik pergantian Pejabat Bupati yang dilakukan oleh Gubernur atau pergantian Bupati dan Wakil Bupati berdasarkan hasil Pemilihan Umum Kepala Daerah(Pemilukada), yang nilainya dinyatakan dalam skor 1 pada waktu terjadi pergantian Kepala Daerah dan skor 0 pada waktu tidak terjadi pergantian Kepala Daerah.

\section{Metode Analisis}

Produk Domestik Regional Bruto (PDRB) merupakan salah satu indikator penting untuk mengetahui kondisi ekonomi di suatu daerah dalam suatu periode tertentu, baik atas dasar harga berlaku maupun atas dasar harga konstan. PDRB pada dasarnya merupakan jumlah nilai tambah yang dihasilkan oleh seluruh unit usaha dalam suatu daerah tertentu, atau merupakan jumlah nilai barang dan jasa akhir yang dihasilkan oleh seluruh unit ekonomi pada suatu daerah.PDRB juga dapat digunakan dalam melihat struktur ekonomi dari suatu wilayah.Struktur ekonomi digunakan untuk menunjukkan peran sektor-sektor ekonomi dalam suatu perekonomian. Sektor yang dominan mempunyai kedudukan paling atas dalam struktur tersebut dan akan menjadi ciri khas dari suatu perekonomian. Struktur ekonomi merupakan rasio antara PDRB suatu sektor ekonomi pada suatu tahun dengan total PDRB tahun yang sama. Struktur ekonomi dinyatakan dalam persentase.

Menganalisis selisih PDRB, Investasi dan Tenaga Kerja dimana perubahan ini mempengaruhi selisih antara PDRB Investasi dan Tenaga kerja tahun sekarang ( $\mathrm{t}$ ) dengan tahun sebelumnya (t-1). Selanjutnya selisih ini dibagi dengan PDRB, Investasi, Inflasi, Tenaga Kerja, pada tahun t dikalikan $100 \%$. Sedangkan masa pergantian kepala daerah memiliki nilai 1 ketika masa pergantian dan 0 untuk tahun bukan masa pergantian kepala daerah.

Model yang digunakan disesuaikan dengan tujuan penelitian, yaitu model logaritma ganda (double logarithm) atau elastisitas konstan (Supranto, 1983) dan (Thomas, 1997) dengan bentuk persamaan sebagai berikut:

$$
Y=\beta_{0} X_{1}^{\beta_{1}} X_{2}^{\beta_{2}} X_{3}^{\beta_{3}} X_{4}^{\beta_{4}} e_{i} \ldots \ldots \ldots \ldots \ldots \ldots \ldots . .(6) \text {. }
$$

Untuk mempermudah dalam memperoleh parameter-parameter koefisien regresi yang diperlukan guna melakukan penaksiran terhadap tingkat laju pertumbuhan ekonomi di Kabupaten Halmahera Timur, berikut tingkat kepekaan perubahan pertumbuhan ekonomi daerah sebagai akibat perubahan dalam faktor-faktor yang mempengaruhinya, maka model tersebut ditransformasikan ke dalam bentuk logaritma, sehingga menjadi:

$$
\log Y=\log \beta_{0}+\beta_{1} \log X_{1}+\beta_{2} \log X_{2}+\beta_{3} \log X_{3}+\beta_{4} X_{4}+e_{i} \ldots \ldots . .(7) \text {. }
$$

di mana:

$\mathrm{Y}=$ laju pertumbuhan ekonomi

$\mathrm{X}_{1}=$ tenaga kerja

$\mathrm{X}_{2}=$ investasi

$\mathrm{X}_{3}=$ tingkat inflasi

$\mathrm{X}_{4}=$ masa pergantian Kepala Daerah (dummy variable) 
$\beta_{0}=$ intersept

$\beta_{1}=$ koefisien regresi tenaga kerja

$\beta_{2}=$ koefisien regresi investasi

$\beta_{3}=$ koefisien regresi tingkat inflasi

$\beta_{4}=$ koefisien regresi peubah pergantian kepala

Daerah, dan

$\mathrm{e}_{\mathrm{i}}=$ kesalahan pengganggu

Selanjutnya untuk mengukur pertumbuhan ekonomi, nilai PDB atau PDRB yang digunakan adalah nilai PDB atau PDRB berdasarkan harga konstan. Hal ini dilakukan karena dengan menggunakan harga konstan, pengaruh perubahan harga (inflasi) telah dihilangkan, sehingga sekalipun angka yang muncul adalah nilai uang dari total output barang dan jasa, perubahan nilai PDB atau PDRB sekaligus menunjukkan perubahan jumlah kuantitas barang dan jasa yang dihasilkan selama periode pengamatan. Rahardja dan Manurung (2005) menunjukkan cara menghitung laju pertumbuhan ekonomi secara sederhana dengan model sebagai berikut:

$$
G_{t}=\frac{P D R B_{t}-P D R B_{t-1}}{P D R B_{t-1}} \times 100 \%
$$

di mana:

$\mathrm{PDRB}_{\mathrm{t}}=$ Produk Domestik Bruto Rielpada tahun $\mathrm{t}$.

PDRB $_{\mathrm{t}-1}=$ Produk Domestik Bruto Riel pada tahun $\mathrm{t}-1$.

$\mathrm{t}=$ kurun waktu pengamatan.

$\mathrm{G}_{\mathrm{t}} \quad=$ pertumbuhan ekonomi periode $\mathrm{t}$.

Jika interval waktu pengamatannya lebih dari suatu periode, maka perhitungan tingkat laju pertumbuhan ekonomi dapat menggunakan model persamaan eksponensial seperti yang dikemukakan Sjafrizal (2005) sebagai berikut:

$P D B R_{t}=P D B R_{0}(1+r)^{t}$ (9).

Melogaritmakan kedua sisi persamaan, sehingga menjadi:

$$
\begin{aligned}
& \log P D B R_{t}=\log P D B R_{0}+t \log (1+r) \\
& t \log (1+r)=\log P D B R_{t}-\log P D B R_{0} \\
& \log (1+r)=\frac{\log P D B R_{t}-P D B R_{0}}{t}
\end{aligned}
$$

$$
\begin{aligned}
& 1+r=\operatorname{anti} \log \frac{P D B R_{t}-P D B R_{0}}{t} \\
& r=\operatorname{anti} \log \frac{P D B R_{t}-P D B R_{0}}{t}-1
\end{aligned}
$$

di mana :

$\mathrm{PDBR}_{\mathrm{t}}=$ Produk Domestik Bruto Riel pada tahun t.

$$
\begin{aligned}
\operatorname{PDBR}_{0}= & \text { Produk Domestik Bruto Riel pada } \\
& \text { tahun awal } \\
\mathrm{t} \quad= & \text { kurun waktu pengamatan } \\
\mathrm{r} \quad= & \text { pertumbuhan ekonomi. }
\end{aligned}
$$

Dengan membatasi ruang lingkup wilayah penelitian ini pada konteks daerah, maka model di atas dapat diterapkan untuk menghitung tingkat laju pertumbuhan ekonomi daerah sebagai berikut:

$$
G_{t}=\frac{P D R B_{t}-P D R B_{t-1}}{P D R B_{t-1}} \times 100 \%
$$

di mana :

$$
\begin{aligned}
\operatorname{PDRB}_{\mathrm{t}}= & \text { Produk Domestik Regional Bruto Riel } \\
& \text { pada tahun } \mathrm{t} . \\
\text { PDRBR }_{\mathrm{t}-1}= & \text { Produk Domestik Regional Bruto } \\
& \text { Riel pada tahun } \mathrm{t}-1 . \\
\mathrm{t} & =\text { kurun waktu pengamatan } \\
\mathrm{G}_{\mathrm{t}} \quad= & \text { pertumbuhan ekonomi periode } \mathrm{t} .
\end{aligned}
$$

\section{HASIL DAN PEMBAHASAN}

\section{Pendugaan Fungsi Pertumbuhan}

Dalam penelitian ini, hanya diteliti empat dari berbagai faktor tersebut yang diduga berpengaruh terhadap pertumbuhan ekonomi di Kabupaten Halmahera Timur, yaitu jumlah tenaga kerja, perkembangan investasi, tingkat inflasi dan pergantian kepala daerah sebagai variabel kategori (dummy variable).

Hubungan antara jumlah tenaga kerja, perkembangan investasi, tingkat inflasi dan pergantian kepala daerah dengan pertumbuhan ekonomi diformulasikan dalam bentuk fungsi pertumbuhan ekonomi daerah. Model yang dipilih adalah model logaritma ganda (double logarithm) atau model elastisitas konstan. Selain jumlah tenaga kerja, perkembangan investasi, dan tingkat inflasi, maka faktor lain yang juga dimasukan ke dalam model adalah pergantian Kepala Daerah sebagai variabel kategori (dummy variable). 
Fungsi pertumbuhan ekonomi Kabupaten Halmahera Timur periode 2004-2014 dengan model logaritma ganda, dengan bantuan aplikasi SPSS ver21, dengan hasil sebagai berikut

Tabel 1. Hasil analisis Varians

\begin{tabular}{llrrrrr}
\hline \multicolumn{6}{c}{ ANOVA $^{\text {a }}$} \\
\hline \multirow{2}{*}{ Model } & $\begin{array}{c}\text { Sum of } \\
\text { Squares }\end{array}$ & Df & $\begin{array}{c}\text { Mean } \\
\text { Square }\end{array}$ & F & Sig. \\
\hline & Regression & .501 & 4 & .125 & 27.598 & $.001^{\mathrm{b}}$ \\
1 & Residual & .023 & 5 & .005 & & \\
\cline { 2 - 4 } & Total & .524 & 9 & & & \\
\hline
\end{tabular}

a Dependent Variabel :Log Y

b Predictors:(Constant), $\log X 4, \log X 3, \log X 2, \log X 1$

Tabel 2 Hasil Analisis Regresi

\begin{tabular}{|c|c|c|c|c|c|}
\hline \multirow[t]{2}{*}{ 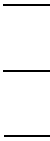 } & \multirow[t]{2}{*}{ Model } & \multicolumn{2}{|c|}{$\begin{array}{l}\text { Unstandardized } \\
\text { Coefficients }\end{array}$} & \multirow{2}{*}{$\begin{array}{c}\begin{array}{c}\text { Standardized } \\
\text { Coefficients }\end{array} \\
\text { Beta }\end{array}$} & \multirow[t]{2}{*}{$\mathrm{t} \quad$ Sig. } \\
\hline & & B & $\begin{array}{l}\text { Std. } \\
\text { Error }\end{array}$ & & \\
\hline \multirow{5}{*}{1} & (Constant) & 1.199 & .225 & & 5.327 .003 \\
\hline & $\log X 1$ & .451 & .055 & 1.110 & 8.142 .000 \\
\hline & $\log X 2$ & -.746 & .261 & -.384 & -2.857 .036 \\
\hline & $\log X 3$ & .196 & .066 & .293 & 2.986 .031 \\
\hline & $\log X 4$ & -.045 & .054 & -.078 & -.822 .449 \\
\hline \multicolumn{4}{|c|}{ a Dependent variabel:Log Y } & & \\
\hline
\end{tabular}

Berdasarkan hasil analisis varians yang di peroleh, terlihat bahwa model analisis regresi yang digunakan cukup baik. Hal ini dengan p_value regression $=0.001$ (lebih besar dari 0.01). Hal ini berarti variabel bebas yang dipilih dapat menjelaskan dengan sangat baik dan sangat signifikan (sangatnyata berpengaruh) terhadap pertumbuhan ekonomi daerah Halmahera Timur. Model regresi ini dapat digunakan sebagai

LOG Y $=1.199+0.4514$ LOG X1 0.746 LOG X2 +0.1957 LOG X3 0.0447 LOG X sebagai model untuk memprediksi perubahan Pertumbuhan Ekonomi (Y) yang dipengaruhi oleh keempat variabel bebas (pertumbuhan tenaga kerja, pertumbuhan investasi, perubahan inflasi, dan ada tidaknya pergantian masa pergantian kepala daerah) di daerah Kabupaten Halmahera Timur.

Hasil ini juga di dukung oleh nilai koefisien etderminasi atau $R-s q=95.67 \%$, yang berarti perubahan dalam pertumbuhan ekonomi sangat di pengaruhi (atau 95.67 persen dipengaruhi) oleh ke empat variabel bebas tersebut.

Selanjutnya, hasil analisis secara parsial (secara masing-masing) pertumbuhan jumlah tenaga, pertumbuhan investasi, perubahan inflasi, dan masa pergantian kepala daerah terhadap variabel pertumbuhan ekonomi. Hasil analisis menunjukkan bahwa keempat variabel bebas model regresi $\mathrm{m}$ terlihat mperlihatkan nilai-nilai $P \_$value dari variabel-variabel $\log \_\mathrm{X} 1, \log \_\mathrm{X} 2$, Log_X3 lebih kecil dari angka 0.05 (dimana pada table output di atas menunjukkan $p_{-}$value untuk Log_X1 $=0.000, \quad p \_v a l u e$ untuk $\log \_\mathrm{X} 2=$ 0.036 , dan $p \_$value untuk Log_X3 $\left.=0.031\right)$; yang berarti ketiga variabel tersebut (perubahan pertumbuhan tenaga kerja, investasi, dan inflasi) secara parsial mempengaruhi secara signifikan terhadap variabel pertumbuhan ekonomi. Kemudian hanya variabel keberadaan pilkada yang nilai $p \_v a l u e n y a$ yang lebih besar dari 0.05 atau variabel.

Berdasarkan nilai dari koefisien regresi yang diperoleh dari variabel pertumbuhan tenaga kerja, yaitu sebesar 0.4514.Dari nilai ini, dapat dinyatakan bahwa apabila pertumbuhan tenaga kerja naik sebesar 2\% maka pertumbuhan ekonomi dapat diprediksi akan mengalami multiplikasi atau perkalian sebesar $2^{(0.4514)}=1.367366514$. Kemudian untuk nilai dari koefisien regresi yang diperoleh dari variabel pertumbuhan investasi, yaitu sebesar-0.746. Dari nilai ini, dapat dinyatakan bahwa apabila pertumbuhan investasi naik sebesar $2 \%$ maka pertumbuhan ekonomi dapat diprediksi akan mengalami multiplikasi sebesar $2^{(-0.746)}=$ 0.596254436 .

Selanjutnya untuk nilai dari koefisien regresi yang diperoleh dari variabel pertumbuhan tenaga kerja, yaitu sebesar 0.1957. Dari nilai ini, dapat dinyatakan bahwa apabila pertumbuhan tenaga kerja naik sebesar $2 \%$ maka pertumbuhan ekonomi dapat diprediksi akan mengalami multiplikasi atau kelipatansebesar $2^{(0.1957)}=1.145279719$ Namun, secara bersama-sama seluruh variabel bebas mempengaruhi variabel pertumbuhan ekonomi Berdasarkan hasilpendugaan model fugsi pertumbuhan ekonomi di Kabupaten Halmahera Timur ternyata:

(1) Dari hasil analisis varian (analysis of varian) semua peubah bebas yang diteliti,yaitu tenga kerja,investasi,tingkat inflasi dan masa pergantian Kepala Daerah berpengaruh positif signifikan terhadap pertumbuhan ekonomi di kabupaten tersebut. Hal itu berarti bahwa hipotesis pertama yang diajukan dalam penelitian ini dibuktikan kebenarannya. 
(2) Semua koefisien regrsesi dari peubah-peubah bebas yang diteliti bernilai kecil dari satu $(\beta<$ 1) yang berarti perubahan pertumbuhan ekonomi diKabupaten Halmahera Timur inelastis baik terhadap perubahan tenaga kerja dan investasi maupun terhadap perubahan tingkat inflasi sehingga hipotesis kedua yang diajukan dalam penelitian ini tidak dapat dibuktikan kebenarannya.

\section{Perkembangan Kesempatan kerja dan Pengangguran}

Kabupaten Halmahera Timur dibentuk berdasarkan Undang-undang Republik Republik Indonesia Nomor 1 Tahun 2003 tentang Pembentukan Kabupaten Halmahera Utara, Kabupaten Halmahera Selatan, Kabupaten Kepulauan Sula, Kabupaten Halmahera Timur dan Kota Tidore Kepulauan di Provinsi Maluku Utara, hasil pemekaran dari Kabupaten Halmahera Tengah. Kabupaten ini memiliki luas wilayah secara keseluruhan 14.202,01 kilometer persegi, yang terdiri dari wilayah daratan seluas $6.506,19$ kilometer persegi $(45,81 \%)$ dan wilayah perairan laut seluas $7.695,82$ kilometer persegi $(54,19 \%)$. Pembentukan Kabupaten Halmahera Timur sebagai daerah otonom selain dimaksudkan untuk memperpendek rentang kendali pemerintahan dalam rangka memberikan pelayanan publik yang lebih baik kepada masyarakat. Di samping itu juga, untuk mempercepat proses pelaksanaan pembangunan guna meningkatkan taraf hidup dan tingkat kesejahteraan masyarakat. Hingga tahun 2014, kabupaten ini memiliki 10 kecamatan.

Tabel 2. Keadaan Tenaga Kerja, Di Kabupaten Halmahera Timur Periode 2004-2014

\begin{tabular}{lrrr}
\hline Tahun & $\begin{array}{c}\text { Jumlah } \\
\text { Tenaga } \\
\text { Kerja }\end{array}$ & Perubahan & $\begin{array}{r}\text { Tumbuh } \\
(\boldsymbol{\%})\end{array}$ \\
\hline 2004 & 38587 & - & - \\
2005 & 40579 & 19992 & 5.16 \\
2006 & 47210 & 6631 & 16.34 \\
2007 & 59088 & 11878 & 25.16 \\
2008 & 65357 & 6269 & 10.61 \\
2009 & 69095 & 3738 & 5.72 \\
2010 & 80510 & 11415 & 16.52 \\
2011 & 84543 & 4034 & 5.01 \\
2012 & 87088 & 2545 & 3.01 \\
2013 & 89831 & 2743 & 3.15 \\
2014 & 90011 & 180 & 0.20 \\
\hline Sumber: Badan Pusat Statistik Kabupaten Halmahera Timur. Data \\
\multicolumn{4}{c}{ diolah dengan jumlah desa sebanyak 102 Desa. } \\
\multicolumn{3}{c}{}
\end{tabular}

Jumlah penduduk Kabupaten Halmahera Timur sesuai hasil registrasi penduduk tahun 2004 sebanyak 53.305 jiwa yang kemudian meningkat menjadi 82.914 jiwa berdasarkan hasil registrasi penduduk tahun 2014 dengan laju pertumbuhan (rate of population growth) sebesar 5,55 \% per tahun. Jika diukur kepadatan penduduk kabupaten ini pada tahun 2004 dan tahun 2014 dengan membandingkan antara jumlah penduduk dengan luas wilayah daratannya, maka pada tahun 2004 kepadatan penduduk rata-rata baru mencapai 8 jiwa/ $\mathrm{Km}^{2}$, sedangkan pada tahun 2014 meningkat menjadi 13 jiwa $/ \mathrm{Km}^{2}$. Tingkat kepadatan penduduk yang demikian masih tergolong jarang dibandingkan dengan tingkat kepadatan penduduk di Kota Ternate yang mencapai $1.819 \mathrm{jiwa} / \mathrm{Km}^{2}$, bahkan Halmahera Timur merupakan kabupaten yang memiliki tingkat kepadatan penduduk terjarang dari 10 Kabupaten/kota yang ada di Provinsi Maluku Utara.

Selain tingkat kepadatan penduduk yang masih relatif jarang, maka masalah lain yang dihadapi dalam karakteristik penduduk Kabupaten Halmahera Timur adalah komposisi penduduk yang berusia muda. Pada tahun 2014, dari jumlah penduduk yang sebesar 82.914 jiwa, komposisinya terbentuk menurut kelompok usia sebagai berikut:

(1) Kelompok usia anak-anak (0-14 tahun) sejumlah 28.531 jiwa atau $34,41 \%$;

(2) Kelompok usia muda (15-39 tahun) sejumlah 36.105 jiwa atau $43,55 \%$; dan

(3) Usia tua (40 tahun ke atas) sejumlah 18.278 jiwa atau 22,04 \%. Permasalahan yang dihadapai terkait dengan komposisi usia penduduk yang demikian adalah selain harus tersedianya sandang dan pangan dalam jumlah yang memadai untuk memenuhi kebutuhan konsumsi penduduk. Di samping itu juga, menuntut penanggulangan masalah kesempatan kerja, sebab jika masalah ini tidak tertanggulangi dengan baik akan menimbulkan gejolak sosial di dalam masyarakat yang dapat menghambat pelaksanaan pembangunan daerah.

Penduduk Kabupaten Halmahera Timur yang terbentuk dengan komposisi penduduk berusia muda sebesar 43,55 \% ditambah kelompok usia anak-anak sebesar 34,41 \%, memang menuntut penanggulangan masalah kesempatan kerja menjadi bagian yang harus mendapat prioritas penting dan strategis dalam kebijakan pembangunan ekonomi daerah. Sebab di satu sisi, perubahan komposisi usia penduduk menuntut tersedianya kesempatan kerja yang memadai untuk menampung jumlah tenaga kerja yang bertambah. Sementara pada sisi yang 
lain, masalah mendasar yang pasti timbul jika kesempatan kerja yang tersedia terbatas adalah meningkatnya tekanan pengangguran di dalam masyarakat. Tekanan pengangguran yang tinggi bukan hanya akan berimplikasi terhadap masalahmasalah ekonomi seperti tingkat ketergantungan penduduk yang besar dan bertambahnya jumlah penduduk miskin, akan tetapi juga menimbulkan masalah-masalah sosial di dalam masyarakat.

Kondisi obyektif penyediaan kesempatan kerja bagi penduduk di Kabupaten Halmahera Timur memperlihatkan bahwa tingkat kesempatan kerja yang tersedia terbatas, yang berakibat angkatan kerja yang dimiliki belum termanfaatkan secara optimal.Data pada Tabel 6. Menunjukkan bahwa, pada tahun 2004, jumlah tenga kerja di kabupaten ini adalah sebanyak 38.587 orang yang kemudian meningkat menjadi 54.847 orang pada tahun 2014 dengan laju pertumbuhan sebesar $3,20 \%$ per tahun. Sementara tingkat kesempatan kerja yang tercipta, yang ditunjukkan oleh banyaknya jumlah angkatan kerja bekerja meningkat dari 22.978 orang pada tahun 2004 menjadi 35.076 orang pada tahun 2014 dengan laju pertumbuhan sebesar 5,27 \% per tahun. Karena penyediaan kesempatan kerja bagi angkatan kerja terbatas, maka tekanan pengangguran angkatan kerja pun meningkat. Selama periode tersebut, tingkat pengangguran angkatan kerja meningkat dari 1.144 orang pada tahun 2004 menjadi sebanyak 1.595 orang pada tahun 2014 atau tumbuh sebesar 3,94\% per tahun. Hal ini juga seperti yang dideskripsikan pada aspek tingkat pengangguran terbuka yang berada pada interval $3,15 \%$ hingga $11,08 \%$ sebagaimana ditunjukkan pada Tabel 6 .

\section{Perkembangan Investasi}

Investasi merupakan salah satu faktor yang mempunyai peranan sangat penting di luar tenaga kerja dan tingkat inflasi dalam mendorong pertumbuhan ekonomi di suatu daerah. Karena peranannya yang demikian penting dalam mendorong pertumbuhan ekonomi daerah melalui peningkatan produksi barang dan jasa, maka kegiatan investasi pada setiap sektor kegiatan ekonomi selalu diupayakan untuk ditingkatkan, baik investasi yang ditanamkan oleh para pengusaha (investasi swasta) maupun investasi yang bersumber dari pemerintah. Khusus untuk investasi swasta, tujuan utama dari kegiatan tersebut selain untuk mendukung para pengusaha dalam memperlancar proses produksi. Di samping itu juga, untuk memudahkan dan membantu semua kegiatan ekonomi dalam menghasilkan barang dan jasa yang dibutuhkan masyarakat.
Adapun perkembangan investasi di Kabupaten Halmahera Timur seperti yang terlihat pada Tabel 3 terlihat peningkatan dari tahun ke tahun mulai tahun 2004 sampai 2014, dengan tingkat pertumbuhan yang fluktuatif. Pertumbuhan tertinggi pada tahun 2005 dan 2010 dimana ini periode ini juga merupakan masa pemilihan kepala daerah.

Tabel 3. Perkembangan Investasi Swasta di Kabupaten Halmahera Timur Periode 2004-2014

\begin{tabular}{lrcr}
\hline Tahun & $\begin{array}{c}\text { Invvestasi } \\
\text { (Milyar Rp.) }\end{array}$ & Perubahan & Tumbuh (\%) \\
\hline 2004 & 143.046 & 19.223 & 13.44 \\
2005 & 162.269 & 18.418 & 11.35 \\
2006 & 180.687 & 17.274 & 9.56 \\
2007 & 197.960 & 18.153 & 9.17 \\
2008 & 216.113 & 18.110 & 8.38 \\
2009 & 234.223 & 29.020 & 12.39 \\
2010 & 263.244 & 20.428 & 7.76 \\
2011 & 283.671 & 20.141 & 7.10 \\
2012 & 303.812 & 18.836 & 6.20 \\
2013 & 322.648 & 18.552 & 5.75 \\
2014 & 341.201 & \\
\hline Sumber data diolah dari: Badan Koordinasi Penanaman Modal (BKPM) \\
\multicolumn{4}{c}{ Kabupaten Halmahera Timur }
\end{tabular}

Investasi sangat diperlukan oleh pemerintah dan pihak swasta untuk mendorong pertumbuhan ekonomi melalui peningkatan produksi barang dan jasa pada semua sektor kegiatan ekonomi. Jumlah investasi yang semakin meningkat dalam perekonomian suatu daerah akan memberikan deksirpsi bahwa, laju pertumbuhan produksi barang dan jasa riel di daerah tersebut juga akan semakin baik.

Hasil analisis regresi menunjukkan bahwa pengaruh pertumbuhan investasi terhadap pertumbuhan ekonomi di Halmahera Timur sebesar 0,746, hal ini berarti peningkatan investasi sebesar $1 \%$ akan meningkatkan pertumbuhan ekonomi sebesar $0,746 \%$.

\section{Perkembangan Inflasi}

Angka inflasi merupakan indiktor penting yang dapat memberikan informasi tentang dinamika perkembangan harga-harga umum barang dan jasa yang dikonsumsi masyarakat. Karena inflasi mengandung pengertian kenaikkan harga-harga umum barang dan jasa kebutuhan masyarakat, maka perubahan tingkat inflasi mempunyai kaitan yang erat dengan fenomena interaksi antara permintaan dan penawaran agregat. Jika barang dan jasa yang diminta masyarakat (konsumen) dalam perekonomian relatif lebih banyak daripada yang ditawarkan pengusaha (produsen), maka tingkat harga umum barang dan jasa akan meningkat dan terjadilah inflasi. Sebaliknya, apabila jumlah barang dan jasa yang diminta masyarakat relatif lebih sedikit dibanding yang ditawarkan pengusaha, maka tingkat harga umum barang dan jasa akan menurun dan menimbulkan deflasi. 
Berdasarkan hasil perhitungan Badan Pusat Statistik Provinsi Maluku Utara, maka laju inflasi di Kota Ternate periode tahun 2004-2014 menunjukkan perkembangan yang bervariasi dengan kecenderungan peningkatan yang rendah, yang mengindikasikan semakin membaiknya kondisi perekonomian di Provinsi Maluku Utara termasuk di kabupaten Halmahera Timur sejalan dengan diimplementasikannya kebijakan pembangunan di berbagai sektor ekonomi. Laju inflasi yang hanya sebesar $4,82 \%$ pada tahun 2004 meningkat rendah menjadi $8,50 \%$ pada tahun 2014 atau tumbuh sebesar 7,63\% per tahun.

Data pada Tabel 5 sesungguhnya memperlihatkan bahwa selama periode 20042014, tingkat inflasi dalam perekonomian Kota Ternate yang digunakan sebagai proksi terhadap perekonomian Kabupaten Halmahera Timur mengalami perkembangan yang bervariasi. Pada tahun-tahun tertentu, mengalami peningkatan yang tinggi dan pada tahun-tahun yang lainnya.

\begin{tabular}{|c|c|c|c|}
\hline Tahun & $\begin{array}{l}\text { Rata-rata } \\
\text { Inflasi }\end{array}$ & Perubahan & Tumbuh (\%) \\
\hline 2004 & 0.4066667 & & \\
\hline 2005 & 0.4132479 & 0.007 & 1.6183333 \\
\hline 2006 & 0.4150111 & 0.002 & 0.4266667 \\
\hline 2007 & 0.4157868 & 0.001 & 0.1869167 \\
\hline 2008 & 0.4196848 & 0.004 & 0.9375 \\
\hline 2009 & 0.4235977 & 0.004 & 0.9323333 \\
\hline 2010 & 0.4254756 & 0.002 & 0.4433333 \\
\hline 2011 & 0.4294627 & 0.004 & 0.9370833 \\
\hline 2012 & 0.4330516 & 0.004 & 0.8356667 \\
\hline 2013 & 0.4365304 & 0.003 & 0.8033333 \\
\hline 2014 & 0.4370033 & 0.000 & 0.1083333 \\
\hline
\end{tabular}

Mengalami penurunan. Karena inflasi diartikan sebagai naiknya tingkat harga barang dan jasa secara umum yang diukur berdasarkan perubahan Indeks Harga Konsumen (IHK). Dengan menggunakan perubahan Indeks Harga Konsumen, maka tinggi rendahnya tingkat inflasi di Kabupaten Halmahera Timur dalam periode tahun 2004-2014 sangat tergantung pada tinggi rendahnya perubahan tingkat harga 300 jenis komoditas pada tahun 2002, perubahan tingkat harga 350 jenis komoditas pada tahun 2007 dan perubahan tingkat harga 397 jenis komoditas pada tahun 2012 yang digunakan Badan Pusat Statistik Provinsi Maluku Utara untuk menyusun Indeks Harga Konsumen di Kota Ternate. Dengan perkataan lain, perubahan Indeks Harga
Konsumen (IHK) di Kota Ternate yang mencerminkan laju inflasi di Provinsi Maluku Utara termasuk di Kabupaten Halmahera Timur sangat tergantung pada perubahan tingkat harga dari jumlah dan jenis komoditas yang digunakan sebagai basis data dalam penyusunan Indeks Harga Konsumen.

Deskripsi tentang inflasi di Kabupaten Halmahera Timur yang diproksi menggunakan laju inflasi di Kota Ternate ini, meskipun cenderung meningkat, akan tetapi masih berada dalam batas yang dapat dikendalikan, sehingga dengan demikian memberikan dampak positif terhadap peningkatan kegiatan ekonomi.

Hasil analisa regresi menunjukkan bahwa pertumbuhan inflasi berpengaruh positif terhadap pertumbuhan ekonomi di Halmahera Timur. Hal ini bertentangan dengan teori yang menyatakan bahwa inflasi akan menurunkan pertumbuhan ekonomi. Jika dilihat dari besarnya tingkat inflasi yang terjadi masih dibawah tingkat inflasi provinsi Maluku Utara. Pengaruh pertumbuhan inflasi terhadap pertumbuhan ekonomi daerah sebesar 1,96, yang memiliki makna bahwa peningkatan inflasi sebesar $1 \%$ akan meningkatkan ekonomi sebesar $1,96 \%$. Dan ini hanya berlaku pada tingkat inflasi pada periode penelitian, dimana menurut informasi yang diperoleh peneliti bahwa emerintah provinsi menahan laju inflasi yang berdampak pada tingkat inflasi yang ada di kabupaten, khususnya Halmahera Timur.

\section{Pergantian Kepala Daerah}

Dalam periode 2004-2014 dilaksanakan dua kali Pemilihan Umum Kepala Daerah (Pemilukada) di Kabupaten Halmahera Timur, yaitu pada tahun 2005 dan tahun 2010. Pelaksanaan Pemilihan Umum Kepala Daerah tersebut bertujuan memilih Bupati dan Wakil Bupati Halmahera Timur untuk periode lima (5) tahun berikutnya. Pada tahun 2005, Pemilukada pertama dilaksanakan yang diikuti oleh empat (4) Pasangan Calon Bupati dan Wakil Bupati.Selanjutnya, pada tahun 2010, Pemilukada kedua dilaksanakan yang diikuti oleh enam (6) Pasangan Calon Bupati dan Wakil Bupati. Pelaksanaan Pemilukada Pertama pada tahun 2005 yang diikuti oleh empat Pasangan Calon Bupati dan Wakil Bupati dimenangkan oleh 
Pasangan Calon Bupati dan Wakil Bupati Nomor Urut 1, yaitu: Welhelmus Tahalele dan Rudy Erawan. Sementara pada pelaksanaan Pemilukada kedua tahun 2010 yang diikuti oleh enam Pasangan Calon Bupati dan Wakil Bupati dimenangkan oleh Pasangan Calon Bupati dan Wakil Bupati Nomor Urut 3, yaitu: Rudy Erawan.dan Muhdin Hi. Mabud.Dengan demikian, selama periode 2004-2014 telah terjadi dua kali pergantian Kepala Daerah di Kabupaten Halmahera Timur berdasarkan hasil Pemilukada.

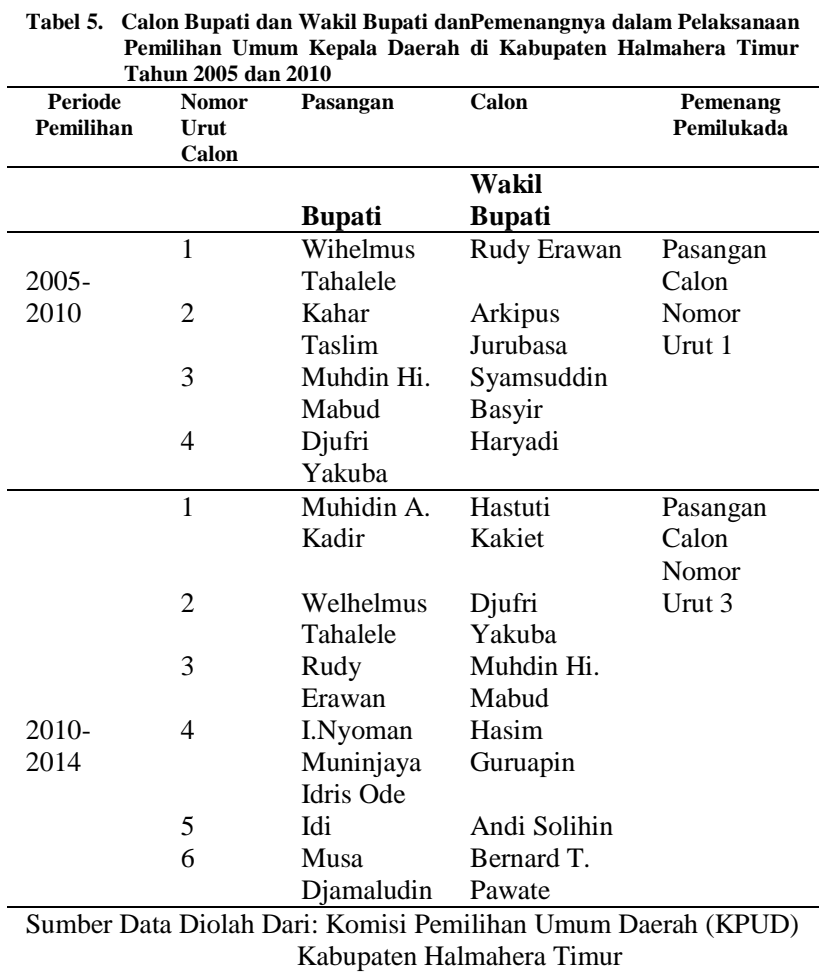

Terjadinya empat kali pergantian Kepala Daerah di Kabupaten Halmahera Timur dalam periode 2004-2014 ini tentunya akan berpengaruh terhadap tingkat laju pertumbuhan ekonomi daerah di kabupaten tersebut.

Masa pemilihan kepala daerah menyebabkan suhu politik di wilayah tersebut meningkat. Persaingan antar calon yang diikuti oleh para pengikut masing-masing calon akan mempengaruhi kondisi keamanan dan ketertiban masyarakat (kamtibmas). Atau dengan kata lain meningkatnya suhu poitik suatu daerah akan meningkatkan country risk wilayah tersebut. Ketika country risk naik maka biasanya investasi menurun dan juga kegiatan dari sisi produksi menurun juga. Hal ini akan berakibat pada terganggunya pertumbuhan ekonomi suatu wilayah.

Hasil penelitian ini menunjukkan bahwa pengaruh masa pemilihan kepada daerah terhadap pertumbuhan ekonomi di Kabupaten Halmahera Timur sebesar 0,45 , yang berarti setiap masa pergantian kepala daerah justru akan meningkatkan pertumbuhan ekonomi sebesar $0,45 \%$. Hasil ini menunjukkan bahwa kondisi kamtibmas Kabupaten Timur cukup baik, sehingga masa pergantian kepala daerah tidak berpengaruh secara negative terhadap pertumbuhan ekonomi, tetapi sebaliknya berpengaruh positif. Hal ini dapat disebabkan karena banyak pengunjung dari luar daerah.

\section{Pertumbuhan Ekonomi}

Pertumbuhan ekonomi yang tinggi merupakan salah satu tujuan yang ingin dicapai Pemerintah Daerah dalam pembangunan ekonomi di Kabupaten Halmahera Timur.Tujuan ini secara jelas terlihat dari perkembangan Produk Domestik Regional Bruto (PDRB) riel periode 2004-2014, yang merefleksikan peningkatan laju pertumbuhan ekonomi daerah. Secara umum selama periode tersebut, kondisi perekonomian regional Kabupaten Halmahera Timur yang diukur berdasarkan perkembangan PDRB riel menunjukkan pertumbuhan positif rata-rata 8,18 $\%$ per tahun. Dari perspektif makro-ekonomi regional, tingkat laju pertumbuhan ekonomi yang demikian memberikan gambaran bahwa pembangunan ekonomi yang dilaksanakan Pemerintah Daerah setempat, telah mampu meningkatkan kinerja ekonomi di berbagai sektor serta menggerakan kondisinya ke arah pertumbuhan yang tinggi dan dinamis.

Perkembangan tingkat laju pertumbuhan ekonomi Kabupaten Halmahera Timur periode 2004-2014 ditunjukkan pada Tabel 7.Berdasarkan data pada tabel tersebut dapat dilihat bahwa, dari segi polanya, tingkat laju pertumbuhan ekonomi tahunan di kabupaten ini memperlihatkan pola yang semakin baik dengan kecenderungan yang meningkat.Meskipun demikian, tingkat laju pertumbuhan tersebut memperlihatkan struktur peningkatan yang bervariasi dan cenderung terkonsentrasi. Pada empat tahun pertama, periode 2004-2007, laju pertumbuhan ekonomi di 
kabupaten ini memiliki pola yang meningkat tinggi dengan interval antara 5,54 \% hingga 10,21 $\%$. Kondisi ini disebabkan meningkatnya kontribusi sektor pertanian, sektor pertambangan dan penggalian serta sektor perdagangan, hotel dan restoran yang cukup besar terhadap pertumbuhan ekonomi daerah dalam periode tersebut.

Tabel 6. Pertumbuhan Ekonomi Kabupaten Halmahera Timur

\begin{tabular}{|c|c|c|}
\hline Tahun & PDRB Riel (Juta Rp) & Pertumbuhan (\%) \\
\hline 2004 & $166.324,8$ & \\
\hline 2005 & $175.561,6$ & 5,55 \\
\hline 2006 & $186.569,3$ & 6,27 \\
\hline 2007 & $205.598,3$ & 10,20 \\
\hline 2008 & $219.851,5$ & 6,93 \\
\hline 2009 & $235.605,1$ & 7,17 \\
\hline 2010 & $252.906,1$ & 7,34 \\
\hline 2011 & $270.635,8$ & 7,01 \\
\hline 2012 & $288.871,7$ & 6,74 \\
\hline 2013 & $306.162,0$ & 5,99 \\
\hline 2014 & $310.111,5$ & 1,26 \\
\hline Rata-rata pertahun & & 8,18 \\
\hline
\end{tabular}
Halmahera Timur.

Memasuki tahun 2008 hingga 2010, laju pertumbuhan ekonomi di Kabupaten Halmahera Timur memiliki pola yang berbeda dengan yang terjadi pada periode 2004-2007, pola peningkatannya cenderung rendah meskipun masih tetap meningkat. Sementara pada periode 2011-2013, peningkatan laju pertumbuhan ekonomi yang terjadi semakin rendah bahkan terkontraksi sebesar $1,26 \%$ pada tahun 2014. Pola peningkatan laju pertumbuhan ekonomi yang demikian disebabkan oleh beberapa hal sebagai berikut:

1. Struktur pertumbuhan ekonomi di Kabupaten Halmahera Timur cenderung terkonsentrasi pada sektor-sektor ekonomi tertentu dengan persentase kontribusi yang sangat besar, seperti pada sektor pertanian, sektor perdagangan, hotel dan restoran, serta sektor pertambangan dan penggalian. Jika dalam periode 2004-2014, tingkat laju pertumbuhan ekonomi agregat yang dihasilkan di kabupaten ini adalah sebesar $8,18 \%$ per tahun dengan kontribusi sektor pertanian sebesar $2,64 \%$ rata-rata per tahun, sektor perdagangan, hotel dan restoran $2,34 \%$ per tahun, serta sektor pertambangan dan penggalian sebesar $1,50 \%$ per tahun sebagaimana yang ditunjukkan pada Tabel 2, maka secara kumulatif ketiga sektor tersebut memberikan kontribusi sebesar $6,48 \%$ per tahun terhadap laju pertumbuhan ekonomi agregat yang dicapai atau ekuivalen dengan $79,22 \%$ nilai PDRB riel yang dihasilkan dalam periode tersebut.

2. Belum terjadi difusi kontribusi yang berimbang secara sektoral terhadap laju pertumbuhan ekonomi, meskipun pada sektorsektor ekonomi tertentu seperti sektor industri pengolahan, sektor jasa-jasa, sektor pengangkutan dan komunikasi, sektor keuangan, persewaan dan jasa perusahaan, serta sektor bangunan, terjadi pertumbuhan yang positif dengan kontribusi yang cukup besar.

Dinamika perekonomian regional Kabupaten Halmahera Timur yang secara rata-rata mengalami pertumbuhan positif $8,18 \%$ per tahun periode 2004-2014, mendeskripsikan semakin membaiknya kondisi makroekonomi di Kabupaten ini yang terrefleksi pada aspek penawaran agregat khususnya perkembangan yang terjadi pada kegiatan di sektor riel. Demikian pula, prospek perkembangan yang semakin baik pada aspek permintaan agregat terutama yang terkait dengan peningkatan tingkat konsumsi masyarakat karena semakin efektif bekerjanya mekanisme pasar. Implikasi dari kondisi yang demikian, selain akan mengakibatkan terciptanya proses penguatan fundamental ekonomi daerah karena semakin besar dan meluasnya sebaran investasi yang mendorong peningkatan kesempatan kerja dan tingkat produktivitas di berbagai sektor ekonomi. Di samping itu juga, akan semakin baiknya taraf hidup dan tingkat kesejahteraan masyarakat karena semakin meningkatnya pendapatan yang dapat dihasilkan dari berbagai sektor kegiatan ekonomi.

Terjadinya peningkatan produksi phisik barang dan jasa (PDRB) riel di Kabupaten Halmahera Timur yang tergambar pada tingkat laju pertumbuhan ekonomi daerah sebesar 8,18\% per tahun.Kondisi ini terutama ditopang oleh pelaksanaan beberapa program dan kebijakan Pemerintah Daerah setempat pada sektor-sektor ekonomi prioritas pendukung pembanguan ekonomi daerah seperti pelaksanaan program dan kebijakan intensifikasi melalui penerapan teknologi pertanian, program dan kebijakan ekstensifikasi serta rehabilitasi pertanian melalui perluasan dan perbaikan areal usaha pertanian, program dan kebijakan pengembangan kegiatan 
usaha pertambangan dan penggalian sumberdaya alam yang bernilai tambah tinggi, serta program dan kebijakan pengembangan kegiatan kewirausahaan industri, perdagangan dan jasa.

Sebagai implikasi dari pelaksanaan beberapa program dan kebijakan pembangunan di bidang ekonomi tersebut, maka sektor pertanian, sektor perdagangan, hotel dan restoran, sektor pertambangan dan penggalian serta sektor industri pengolahan yang menjadi andalan perekonomian Kabupaten Halmahera Timur meningkat masingmasing sebesar 5,55 \%, 13,48 \%, 9,89\% dan $11,00 \%$ per tahun dengan besaran kontribusi terhadap pertumbuhan ekonomi daerah masingmasing sebesar 2,64 \%, 2,34 \%, 1,50\% dan 0,60 $\%$ per tahun. Sektor-sektor ekonomi lain seperti sektor keuangan, persewaan dan jasa perusahaan, sektor listrik, gas dan air bersih, sektor bangunan, sektor jasa-jasa serta sektor pengangkutan dan komunikasi, meskipun mengalami pertumbuhan positif yang tergolong cukup besar, akan tetapi besaran kontribusinya terhadap pertumbuhan ekonomi daerah masih relatif rendah, rata-rata di bawah $0,32 \%$ per tahun atau memberikan kontribusi terhadap pertumbuhan ekonomi yang lebih rendah dari kontribusi sektor industri pengolahan.

Pembangunan ekonomi Kabupaten Halmahera Timur yang semakin dinamis dan menghasilkan laju pertumbuhan yang cukup tinggi periode 2004-2014 sesuai dengan tujuan, sasaran, arah dan prioritas pembangunan ekonomi daerah. Sesuai dengan tujuan dan sasaran utama pembangunan ekonomi di kabupaten ini yaitu terciptanya peningkatan produksi barang dan jasa untuk memenuhi kebutuhan konsumsi penduduk dan peningkatan kesempatan kerja di semua sektor dalam rangka mengurangi tingkat pengangguran angkatan kerja, maka pengembangan kegiatan ekonomi di kabupaten ini diarahkan pada upaya penciptaan dan perluasan lapangan kerja yang mampu menyerap tenaga kerja dalam jumlah yang memadai. Tujuan yang hendak dicapai selain terbukanya kesempatan kerja seluas mungkin yang dapat mengurangi pengangguran terbuka.Di samping itu juga, terciptanya tingkat laju pertumbuhan ekonomi daerah yang tinggi, yang tercermin pada peningkatan produksi barang dan jasa riel yang didukung oleh stabilitas ekonomi yang tetap terjaga melalui upaya pengelolaan sumberdaya alam yang mengarah pada pengutamaan prinsip pembangunan berkelanjutan di seluruh sektor.

Untuk dapat mewujudkan tujuan dan sasaran tersebut, maka program prioritas dan kebijakan pembangunan ekonomi daerah yang dilaksanakan Pemerintah Kabupaten Halmahera Timur, diarahkan pada upaya untuk:

1. Meningkatkan kinerja perekonomian daerah di semua sektor kegiatan ekonomi yang produktif dengan memberi ruang yang luas kepada para pelaku usaha dan bisnis untuk mendorong pertumbuhan ekonomi; dan

2. Melakukan upaya peningkatan penyehatan dan penertiban lembaga-lembaga perbankan dalam rangka meningkatkan peran lembagalembaga tersebut sebagai intermediasi ke sektor-sektor produksi. Dampak yang ditimbulkan dari pelaksanaan kebijakan pembangunan ekonomi tersebut adalah terciptanya laju pertumbuhan ekonomi daerah yang tinggi, yang memberikan dampak positif yang besar terhadap peningkatan pendapatan masyarakat.

Dalam periode 2004-2014, pendapatan perkapita riel penduduk Kabupaten Halmahera Timur terus meningkat setiap tahun dan mencapai rata-rata $\mathrm{Rp} \mathrm{3,06} \mathrm{juta/kapita} \mathrm{per} \mathrm{tahun,} \mathrm{yang}$ memberikan indikasi semakin membaiknya taraf hidup dan tingkat kesejahteraan penduduk di daerah iniDari aspek permintaan, sampai dengan tahun 2014 permintaan agregat masyarakat di Kabupaten Halmahera Timur terus mengalami peningkatan sebagai akibat kenaikkan konsumsi yang didorong oleh semakin membaiknya perekonomian daerah bersamaan dengan semakin pulihnya kondisi ekonomi nasional pasca krisis ekonomi serta meningkatnya kepercayaan konsumen (masyarakat). Pola ekspansi kegiatan ekonomi di kabupaten ini hingga tahun tersebut lebih didominasi oleh peningkatan konsumsi masyarakat dan pemerintah. Untuk keadaan pada tahun 2010-2014, konsumsi masyarakat (C) dan konsumsi pemerintah (G) tumbuh masingmasing sebesar $4,63 \%$ dan $9,44 \%$ per tahun dengan kontribusiterhadap pertumbuhan ekonomi sebesar $1,74 \%$ per tahun dan $1,98 \%$ per tahun. Sementara itu, kegiatan investasi terutama yang investasi swasta mulai menunjukkan peningkatan yang berarti antara lain sebagai akibat 
meningkatnya ketersediaan sumber-sumber pembiayaan termasuk dari sektor perbankan. Dalam periode 2010-2014, pengeluaran investasi agregat di kabupaten ini tumbuh 17,52\% dengan besaran kontribusi terhadap pertumbuhan ekonomi daerah sebesar 5,66\% per tahun.

Kegiatan ekspor dan impor barang dan jasa di Kabupaten Halmahera Timur belum memperlihatkan kontribusi yang berarti karena kabupaten ini baru dimekarkan pada tahun 2003 dari Kabupaten Halmahera Tengah sebagai Kabupaten Induk, sehingga peranan sektor ekspor dan impor belum memiliki kontribusi yang berarti terhadap pertumbuhan ekonomi daerah. Upaya untuk mendorong peranan sektor perdagangan baru sebatas pada peningkatan aktivitas perdagangan domestik, baik perdagangan regional dengan kabupaten/kota lain di kawasan Provinsi Maluku Utara maupun maupun perdagangan domestik dengan daerah-daerah lain di Indonesia. Tiga program dan kebijakan perdagangan yang dilaksanakan Pemerintah Kabupaten Halmahera Timur untuk mendorong peranan sektor perdagangan domestik terhadap pertumbuhan ekonomi daerah adalah program dan kebijakan peningkatan kualitas komoditas perdagangan, program dan kebijakan pengembangan jaringan kerja antarlembaga dan jaringan informasi perdagangan agar mampu merespon kebutuhan dunia usaha terutama para pedagang kecil dan menengah, serta program dan kebijakan penguatan kelembagaan persaingan usaha dan bisnis yang mencakup pengembangan kualitas sumberdaya manusia pada sektor perdagangan, serta sarana dan prasarana pendukungnya.

Meskipun Pemerintah Kabupaten Halmahera Timur telah berupaya secara maksimal dengan melaksanakan sejumlah program dan kebijakan di sektor perdagangan domestik, akan tetapi pada tahun 2010-2014, hasil perdagangan neto antardaerah di kabupaten ini belum memberikan kontribusi yang memadai terhadap pertumbuhan ekonomi daerah, bahkan besaran kontribusinya terkontraksi sebesar minus 10,95\% per tahun. Kondisi tersebut terjadi disebabkan nilai neto perdagangan domestik yang dihasilkan pada tahun 2014 mengalami penurunan sebesar Rp 426.556,07 juta dibanding dengan nilai neto perdagangan domestik pada tahun 2010 yang sebesar $\mathrm{Rp} 254.764,55$ juta atau secara rata-rata mengalami pertumbuhan negatif sebesar 66,86\% per tahun. Walaupun dilihat dari aspek permintaan dengan Menggunakan nilai PDRB penggunaan yang dihitung atas dasar harga konstan, peranan sektor perdagangan belum terlalu dominan dalam menentukan tingkat laju pertumbuhan ekonomi di Kabupaten Halmahera Timur, akan tetapi dengan laju pertumbuhan yang positif sebesar $1,86 \%$ per tahun periode 2010-2014, hal ini memberikan informasi bahwa upaya Pemerintah Daerah setempat dalam pelaksanaan pembangunan ekonomi daerah dipandang cukup berhasil.

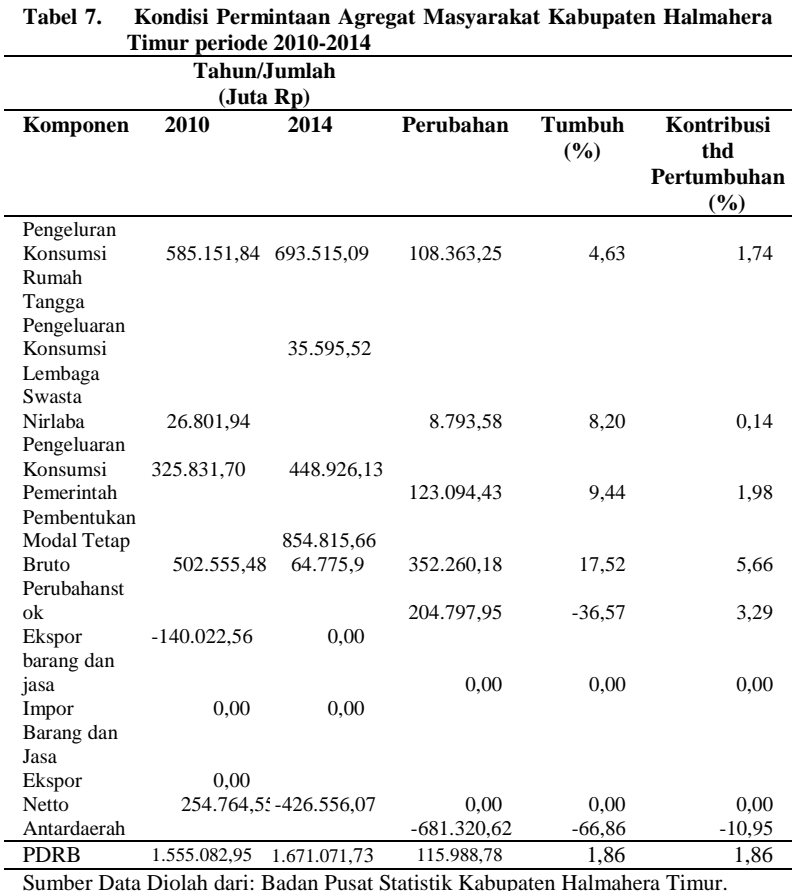

\section{KESIMPULAN DAN SARAN}

\section{Kesimpulan \\ Berdasarkan pembahasan hasil-hasil penelitian, dapat di tarik beberapa kesimpulan sebagai berikut:}

1. Kegiatan investasi dalam pembangunan ekonomi di Kabupaten Halmahera Timur mengalami peningkatan yang cukup tinggi selama periode 2004-2014. Dalam periode tersebut, kegiatan investasi pada semua sektor ekonomi di kabupaten ini tumbuh rata-rata 12 , 
$31 \%$ per tahun. Secara serempak semua peubah bebas yang diteliti, hanya 3 variabel yaitu tenaga kerja, investasi, tingkat inflasi, berpengaruh signifikan terhadap pertumbuhan ekonomi di Kabupaten Halmahera Timur. Sedangkan variabel keberadaan Pilkada tidak berpengaruh signifikan terhadap pertumbuhan ekonomi $Y(p>0,05)$.

2. Pembangunan ekonomi di Kabupaten Halmahera Timur periode 2004-2014 berhasil menciptakan laju pertumbuhan yang cukup tinggi, rata-rata $8,18 \%$ per tahun. Perkembangan tingkat inflasi regional di Kabupaten Halmahera Timur periode 20042014 yang diproksi menggunakan perkembangan laju inflasi tahun kalender (Januari-Desember) di Kota Ternate relatif terkendali pada tingkat 7,63\% per tahun.

\section{Saran}

Selain kesimpulan, dapat pula direkomendasikan beberapa hal sebagai saran:

1. Untuk mendorong peningkatan kesempatan kerja guna mengurangi tekanan pengangguran penduduk, Pemerintah Kabupaten Halmahera Timur perlu memprioritaskan pelaksanakan program perbaikan iklim ketenagakerjaan melalui pengembangan kebijakan pasar tenaga kerja yang fleksibel dengan dukungan sebaran investasi yang proporsional pada semua sektor ekonomi, serta peningkatan kualitas dan kemandirian tenaga kerja yang mampu bersaing di pasar tenaga kerja melalui program pendidikan dan pelatihan dalam pembangunan sektor ketenagakerjaan di daerah ini. Di samping itu juga diupayakan penataan hubungan industrial yang mencerminkan asas keadilan dan pemerataan bagi penduduk dalam perolehan kesempatan kerja.

2. Untuk mendorong tingkat laju pertumbuhan ekonomi yang lebih dinamis dalam rangka mempercepat proses peningkatan taraf hidup dan tingkat kesejahteraan masyarakat di masa-masa mendatang, maka kebijakan dan prioritas pembangunan ekonomi daerah di Kabupaten Halmahera Timur harus diimplementasikan pada lima (5) sektor ekonomi yang memberikan kontribusi besar terhadap pertumbuhan ekonomi, yaitu sektor pertambangan dan penggalian, sektor pertanian, sektor perdagangan, hotel dan restoran, sektor industri pengolahan, serta sektor bangunan (konstruksi).

\section{DAFTAR PUSTAKA}

.1997.Undang-undang Republik Indonesia Nomor 25 Tahun 1997 tentang Ketenagakerjaan. Percetakan Negara Republik Indonesia, Jakarta.

.2015. Statistik Indonesia. Badan Pusat Statisti (BPS), Jakarta.

Rahardja, P dan Manurung, M. 2005. Teori Ekonomi Makro; Suatu Pengantar. LPFE Universitas Indonesia, Jakarta.

Rasyid, R. Gaffar, A, Syaukani, H. 2002.Otonomi Daerah dalam Negara Kesatuan. Diterbitkan Atas Kerja Sama Pustaka Pelajar dengan Pusat Pengkajian Etika Politik dan Pemerintahan, Yogyakarta.

Suparmoko, M. 2000. Pokok-pokok Ekonomika. Edisi Pertama. BPFE-UGM, Yaogyakarta.

Supranto, J. (1983). Ekonometrik: Buku Satu. Lembaga Penerbit Fakultas Ekonomi Universitas Indonesia, Jakarta.

Syafrizal. 2005. Teknik Praktis Penyusunan Rencana Pembangunan Daerah. Baduose Media, Jakarta.

Syaukani, HR. 2002. Otonomi Daerah dalam Negara Kesatuan.Diterbitkan atas Kerja Sama Pustaka Pelajar dan PPEPP, Yogyakarta.

Thomas, R. L. 1997. Modern Econometrics: An Introduction. Addison Wesley Longman, Edinburgh Gate, England. 